\title{
ADSORPTIVE REMOVAL OF CHROMIUM BY DRIED BROWN ALGA SARGASSUM HORNSCHUCHII
}

\author{
Eman M. Fakhry ${ }^{1}$, Suzan Ismail ${ }^{2}$, Nadia H. Noaman ${ }^{1}$, Magda A. \\ Shafik $^{2}$ and Wafaa M. Menesi ${ }^{2}$ \\ ${ }^{1}$ Department of Botany and Microbiology, Faculty of Science, Alexandria \\ University, Egypt. \\ ${ }^{2}$ Department of Biological and Geological Sciences, Faculty of Education, \\ Alexandria University, Egypt
}

\begin{abstract}
Adsorption of hexavalent chromium using dried macro-alga Sargassum hornschuchii was studied under controlled laboratory conditions. Experimental parameters such as contact time, biomass dosage and $\mathrm{pH}$ were studied in a metal concentration of 25 $\mathrm{mg} \mathrm{L}^{-1}$. The adsorption of chromium was fast at the initial phase of study and gradually with time became slowly. The maximum removal percentage of chromium was statistically significant and it was found to be $99.36 \%$ at $36 \mathrm{hrs}$ and $\mathrm{pH} 3$ using $8 \mathrm{~g} \mathrm{~L}^{-1}$ algal dosage. Five consecutive adsorption / desorption cycles were operated on metal solution using $0.1 \mathrm{M} \mathrm{NaOH}$ and $0.1 \mathrm{M} \mathrm{HCl}$. It was found that chromium adsorption decreased following each adsorption / desorption cycle. Results indicated the superiority of $\mathrm{HCl}$ for the recovery of chromium from algal biomass. The present investigation shows that the locally biosorbent Sargassum hornschuchii possesses high adsorption performance with regard to the removal of chromium from its aqueous solution.

Keywords: Adsorption; Chromium; Removal percentage; Sargassum hornschuchii.
\end{abstract}

\section{Introduction}

The discharge of heavy metals into aquatic ecosystems has become a matter of concern in the world. Heavy metals are among the conservative pollutants that are not subject to bacterial attack or other breakdown or degradation. As a result, their concentrations often exceed the permissible levels normally found in soil, waterways and sediments. Actually, when heavy metals accumulate in the environment and in food chains, they can profoundly disrupt biological processes (El-Nady and Atta, 1996).

The need for economical, effective and safe methods for removing heavy metals from wastewaters has resulted in the search for unconventional materials that may be useful in reducing the levels of heavy metals in the environment. Consequently, biological materials have emerged as an ecofriendly and economic option (Davis et al., 2000 and Gupta et al., 2000).

Among the biological materials investigated for heavy metal removal, the biomass of marine algae, otherwise known as seaweeds, has been reported to have high uptake capacities for a number of heavy metal ions (Senthilkumar $\boldsymbol{e t}$ al., 2006, Brinza et al., 2009 and Esmaeili et al., 2011). Several experiments were 
conducted to compare the ability of many macro-algae for removing heavy metals (Romera et al., 2007 and Onyancha et al., 2008). They have been found to be very effective in removing heavy metal from water because of their large surface area, high binding affinity and their cheap availability (Tsui et al., 2006, Murphy et al., 2008 and Liu et al., 2009).

Brown algae among the various groups of algae received the most attention owing to their high uptake capacity (Romera et al., 2006 and Brinza et al., 2007). Non-viable algal biomass frequently exhibits a higher affinity for metal ions compared with viable biomass. This is probably due to the absence of competing protons produced during metabolism. Moreover, drying and grinding biomasses reveal the sites where metal ions could be sequestered and so increase the probability of encountering metal ions. Besides, the metal removal system using dried biomass is not subject to toxicity limitations (Rocha et al., 2006, Parameswari et al., 2009 and Mane et al., 2010).

Many studies have indicated that a number of factors may affect the biosorption process, such as $\mathrm{pH}$ (Rezaee et al., 2005 and Lia et al., 2006), biomass concentration (Gong $\boldsymbol{e t}$ al., 2005), heavy metal concentration (Kiran $\boldsymbol{e t}$ al., 2005) and contact time (Devi et al., 2010).

The application of biosorption as a viable commercial technique implies the recovery of bound metals and the subsequent recycling of the biosorbents (Schiewer and Volesky, 2000). Reusability of sorbent can be evaluated by comparing the sorption potential of regenerated biomass with the original biomass (Zhao et al., 1999). There are several different types of eluent agents (Vijayaraghavan et al., 2004 and Deng et al., 2007) such as organic and inorganic acids solutions and complexing agents (Hashim et al., 2000 and Gong et al., 2005). One of the best desorbent agents for metal desorption are the acids (Lodeiro et al., 2006).

Industries such as leather tanning, petroleum refining, and pulp production generate large quantities of chromium in the environment. Chromium is present in the industrial effluents as trivalent and hexavalent. Trivalent chromium is relatively less toxic and less mobile (Anderson, 1997), while hexavalent chromium is toxic, carcinogenic and mutagenic to animals as well as humans (Costa, 2003). Different governments regulated the concentration of $\mathrm{Cr}$ in discharges to be less than $0.5 \mathrm{mg} \mathrm{L}^{-1}$ irrespective of its oxidation state (Bishnoi $\boldsymbol{e t}$ al., 2007). This has lead to removal of chromium from wastewater before discharge. However, the current methods being employed such as chemical precipitation are not feasible to reduce the concentration to $0.5 \mathrm{mg} \mathrm{L}^{-1}$ meanwhile, various biosorbents offers a potential alternative (Han et al., 2007). Chromium possesses a high oxidation state and high solubility. These characteristics make the remediation process of chromium difficult (Smith and Gadd, 2000). Only the $\mathrm{Cr}$ (VI) ion is capable of passing through cell membranes, hence the oxidation of 
$\mathrm{Cr}$ (III) to $\mathrm{Cr}$ (VI) facilities the bioavailability of chromium. $\mathrm{Cr}$ (VI) is the form of chromium that is mostly found at contaminated sites (Dirilgen, 1998).

The goal of the present investigation is to assess the potential of dried marine brown alga, namely Sargassum hornschuchii to adsorbe Cr (VI) from aqueous solution. The effect of contact time, $\mathrm{pH}$ and algal dosage were studied. This study plays a role in understanding the adsorption phenomenon and help in the development of algal adsorption efficiency.

\section{Materials and Methods}

\section{Adsorbent:}

Sargassum hornschuchii (Plate 1) is a brown macroalga, harvested from the cost of Abu-Qir, Alexandria, Egypt. It is best known for its brown or dark green color. Generally, it consists of a holdfast, a stipe, and a frond. Oogonia and antheridia occur in conceptacles embedded in receptacles on special branches. Some species have berry like gas-filled bladders, which help keep the fronds afloat to promote photosynthesis. The samples of algal biomass were washed with distilled water 2-3 times to remove dirties, sand and epiphytes. The samples were subsequently kept on filter papers, then sun dried for 6 hours followed by drying in an oven at $40{ }^{\circ} \mathrm{C}$ till constant weight. The dried samples were then ground using a mortar, stored in powdered form for following analysis.

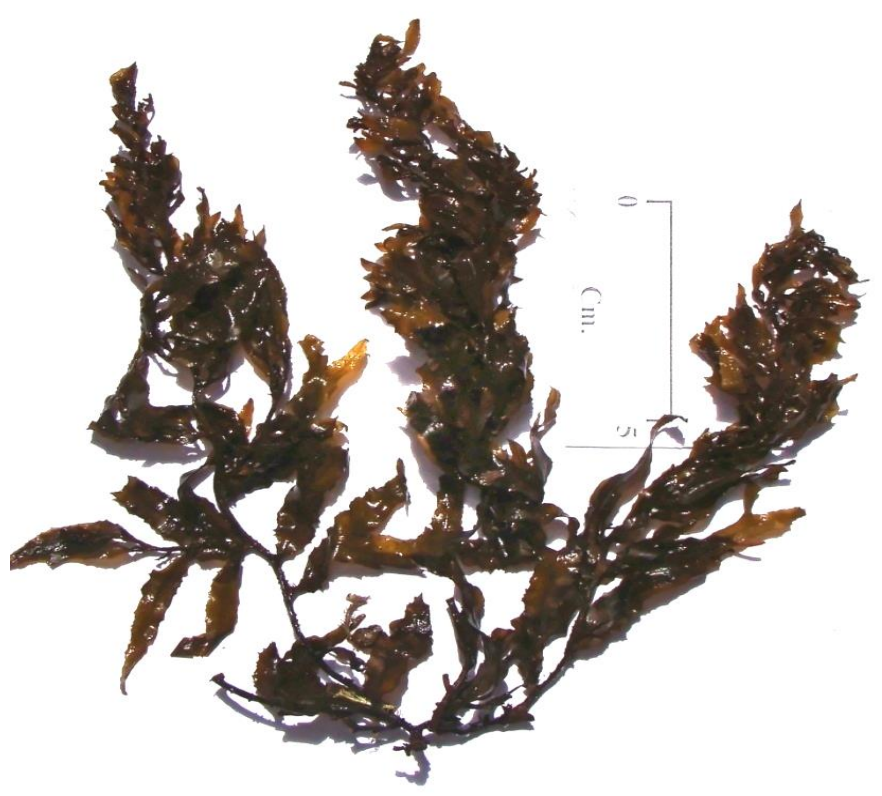

Plate (1): Sargassum hornschuchii C. Agardh. 


\section{Metal solution:}

Metal solution of chromium was prepared by dissolving $25 \mathrm{mg}$ of potassium dichromate $\left[\mathrm{K}_{2} \mathrm{Cr}_{2} \mathrm{O}_{7}\right]$ in 1 liter deionized distilled water. The adsorption capacities have been estimated using Perkin Elmer 2380 atomic absorption spectrophotometer. The samples were diluted, whenever necessary. All experiments were conducted in duplicate at constant temperature of $25 \pm 1^{\circ} \mathrm{C}$ to be representative in environmentally relevant condition.

\section{Effect of contact time:}

The experiment was performed by mixing $0.4 \mathrm{~g}$ of dried alga in $100 \mathrm{ml}$ of metal solution. $\mathrm{pH}$ of solution was kept without treatment. The mixture was periodically agitated for pre-defined time in the range of 6 to $48 \mathrm{hrs}$ with $6 \mathrm{hrs}$ interval in between. The solid biomass was separated from the liquid phase and the later was analyzed for the concentration of chromium ions.

\section{Effect of algal dosage:}

Different dry algal dosages in range, 1 to $10 \mathrm{~g} \mathrm{~L}^{-1}$ were contacted with a series of $100 \mathrm{ml}$ chromium solutions in a concentration of $25 \mathrm{mg} \mathrm{L}^{-1}$. The samples were shaken for the desired time and finally were collected from the aqueous phase. Then, solutions were analyzed for residual metal concentration.

\section{Effect of pH:}

The effect of $\mathrm{pH}$ on chromium removal was examined by varying the $\mathrm{pH}$ of the solution from 1 to 9 . The $\mathrm{pH}$ was adjusted by $0.1 \mathrm{M} \mathrm{HCl}$ and $0.1 \mathrm{M} \mathrm{NaOH}$ solutions using a pH meter (model WPA LINTON CAMBRIDGE UK. CD 620). Dried biomass samples were added. Flasks were continuously shaken and samples were taken after the desired time. Thereafter, the dried algal materials were removed through filtration. The concentration of chromium was determined in filtrate.

\section{Desorption and reuse of biosorbents:}

For adsorption/desorption study, dried biomass was contacted with $100 \mathrm{ml}$ $\mathrm{Cr}$ (VI) solution $\left(25 \mathrm{mg} \mathrm{L}^{-1}\right)$ with periodically agitation for 36 hours. After that, algal biomass was separated by filtration, washed with distilled water for three times to remove residual $\mathrm{Cr}$ (VI) on the surface and dried via filter paper. Subsequently, it was transferred to $25 \mathrm{ml}$ of desorption solutions: $0.1 \mathrm{M} \mathrm{NaOH}$ and $0.1 \mathrm{M} \mathrm{HCl}$ (Jalali et al., 2002, Bishnoi et al., 2007 and Brinza et al., 2007) and mixtures were shaken for 1 hour. The adsorption/desorption study was conducted again by removing the algal biomass from desorbing medium, washing with distilled water and reconditioning for adsorption in the succeeding cycle and this cycle was carried out for five times. After each cycle, sample of metal solution was analyzed by atomic adsorption spectrophotometer to evaluate the adsorption capacity of alga. 


\section{Determination of the adsorption capacity:}

The metal removal percentage was evaluated (Basha et al., 2007, Saratale et al., 2009 and Tan et al., 2009) from the following equation:

\section{Removal percentage of metal \% $=\mathrm{Ci}-\mathrm{Cf} / \mathrm{Ci} \mathbf{X 1 0 0}$}

Where, $\mathrm{Ci}$ is the initial metal ion concentration before adsorption process in $\mathrm{mg} \mathrm{L}^{-1}$ and $\mathrm{Cf}$ is the equilibrium metal ion concentration after adsorption process in $\mathrm{mg} \mathrm{L}^{-1}$.

\section{Statistical analysis:}

Statistical analysis employed SPSS version 10.0 for testing significance of differences between treatments at the 0.05 probability level $(\mathrm{P} \leq 0.05)$. The experiments were tested with analysis of variance (ANOVA).

\section{Results and Discussion}

\section{Effect of contact time:}

Figure (1) illustrates the effect of contact time on the removal percentage of chromium by S. hornschuchii. It is clear that the concentration of metal in the solution was significantly reduced by increasing contact time till $36 \mathrm{hrs}$. This reducing was fast at initial stage of the contact period and became slower with increase in time. This finding suggested that the availability of a large number of vacant sites on the algal surface for adsorption during the initial stage of time. Over time, the remaining vacant surface sites were difficult to be occupied due to the repulsive forces between the solute molecules on the solid and bulk phase (Kumar et al., 2010).

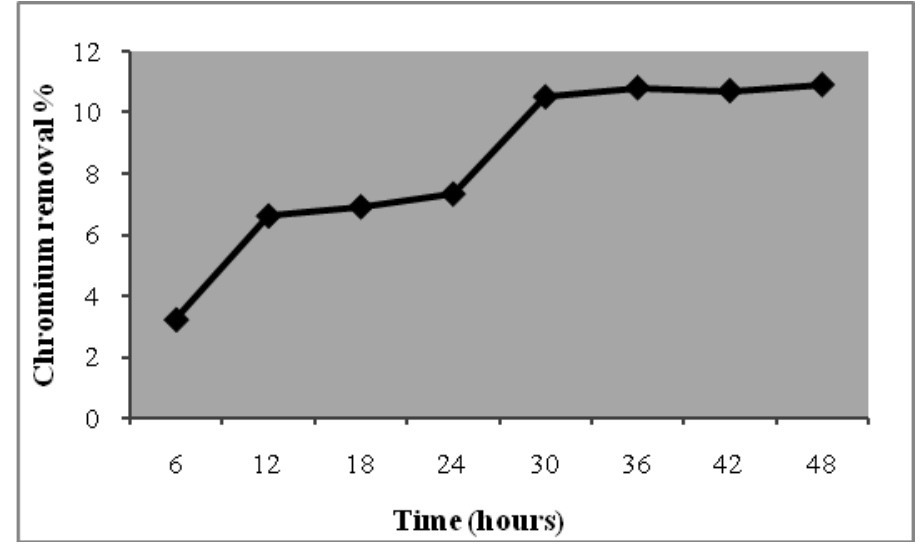

Figure (1): Removal percentage of chromium by $S$. hornschuchii dry biomass at different time periods. 


\section{Effect of algal dosage:}

The adsorption efficiency of $S$. hornschuchii for chromium ions as a function of biomass dosage was investigated. Fig. 2 shows a steeply increase in removal percentage of metal with the biomass loading up to $8 \mathrm{~g} \mathrm{~L}^{-1}$. At this point, the maximum removal percentage of chromium was statistically significant with a percent of $59.68 \%$ and it was almost the same at higher dosages. Actually, for a fixed initial metal concentration, increasing adsorbent dose provided a greater surface area, which could accommodate a higher quantity of metal. However, due to the equilibrium limitation, the quantity of metals being adsorbed for a certain unit surface area of adsorbent slightly decreased. Since near the equilibrium, the remaining vacant surface sites were difficult to be occupied as there is strong repulsion between adsorbate ions bound to active sites of adsorbent and other free ions in solution to occupy the vacant sites. Similar findings were obtained by Sari and Tuzen (2008) who used the dried red alga Ceramium virgatum for the first time for the removal of chromium and reported the maximum biosorption yield (90\%) at about biomass dosage $10 \mathrm{~g} \mathrm{~L}^{-1}$. Singh (2007) observed increase in percentage removal of $\mathrm{Ni}$ (II) with increase in algal dose of Oscillatoria sp. or Spirogyra sp. from 1 to $10 \mathrm{~g} \mathrm{~L}^{-1}$. Gupta and Rastogi (2009) postulated that the adsorption of chromium ions by Oedogonium hatei increased with increasing the algal dosage and the adsorption was almost constant at dose higher than $5 \mathrm{~g} \mathrm{~L}^{-1}$.

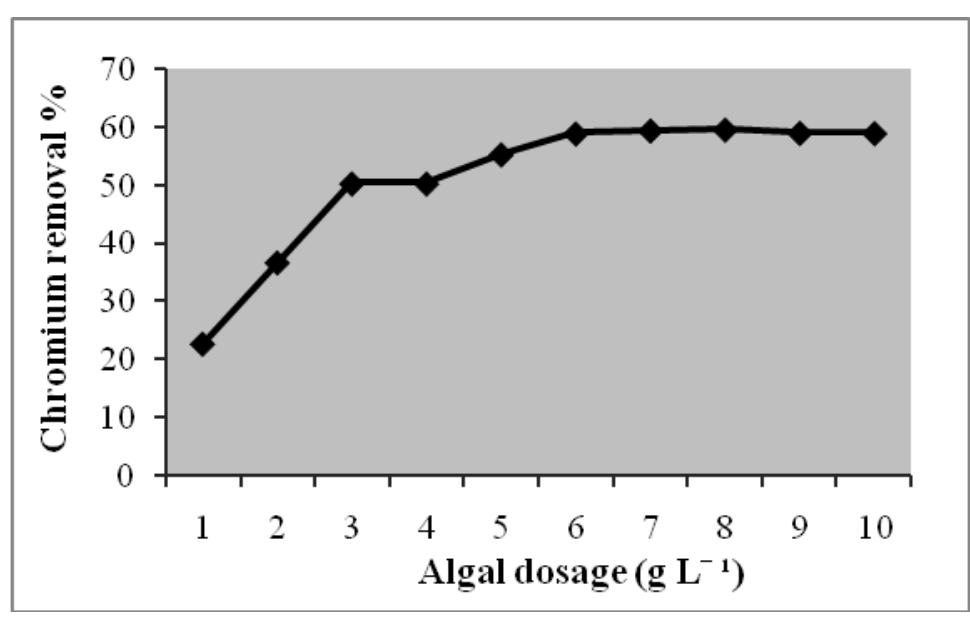

Figure (2): Removal percentage of chromium using different dry biomass dosage of S. hornschuchii.

In contrast, Mehta and Gaur (2001) reported that at given equilibrium concentration, the biomass takes up more metal ions at lower than at higher algal 
doses. The decrease in biosorption process with increase algal dose could be explained as a consequence of partial aggregation of the algal mass at higher concentration, which results in the decrease in effective surface area for the adsorption (Karthikeyan et al., 2007). Merrin $\boldsymbol{e t}$ al. (1998) also suggested that the higher biomass concentration caused screen effect of dense outer layer, blocking the binding sites from metal ions, resulting in lower metal removal per unit biomass.

\section{Effect of pH:}

The $\mathrm{pH}$ of the solution influence significantly both metal binding sites on the cell surface and the chemistry of metal in solution (Dursun, 2006). Heavy metals are taken up from water predominantly by ion exchange. Carboxyl and sulphate groups have been identified as the main metal-sequestering sites in seaweed and, as these groups are acids, its availability is $\mathrm{pH}$ dependent (Cossich et al., 2002). Sargassum sp. presents a high content of ionizable groups (carboxyl groups from mannuronic and guluronic acids) on the cell wall polysaccharides, which makes it, at least in theory, very liable to the influence of the $\mathrm{pH}$ (Antunes et al., 2003). From Fig. 3, a trend of increasing chromium adsorption by the studied adsorbent with increasing $\mathrm{pH}$ could be observed for $\mathrm{pH}$ values in range of 1 to 3, where the removal percentage of metal increased from 51.48 to $99.36 \%$. Consequently, the maximum removal efficiency for chromium was observed at $\mathrm{pH} 3$, while it decreased when the $\mathrm{pH}$ exceeded this value. This may be due to that increased positive charge $\left(\mathrm{H}^{+}\right)$density on the sites of biomass surface at low $\mathrm{pH}$ values ( $\mathrm{pH} 1$ to 3 ) restricted the approach of metal cations as a result of repulsive force.

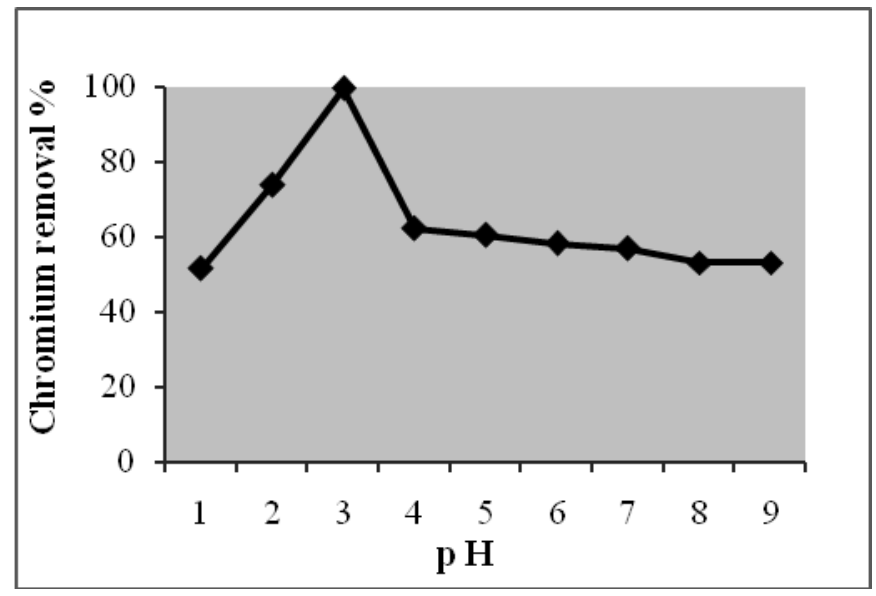

Figure (3): Removal percentage of chromium by Sargassum hornschuchii dry biomasses at different $\mathrm{pH}$ values. 
In contrast, when the $\mathrm{pH}$ value increased, biomass surface was more negatively charged and the adsorption of the metal ions with positive charge $\left(\mathrm{Cr}^{6+}\right)$ was reached maximum around $\mathrm{pH}$ 3. Similar interpretations were also reported in many literatures for metal biosorption (Rezaee $\boldsymbol{e t}$ al., 2006; Rakesh et al., 2010). As the $\mathrm{pH}$ increased more than 3 , anionic hydroxide complexes of the metal ions were formed and competed with the active sites leading to decrease in adsorption rate. This reasoning is in agreement with that of Antunes et al. (2003) and Kumar et al. (2006 and 2007).

\section{Desorption and reuse of biosorbents:}

Biotechnological exploitation of biosorption technology for removal of heavy metal(s) depends on the efficiency of the regeneration of biosorbent after metal desorption (Gupta et al., 2000), where this regeneration is crucially important for keeping the process cost down. Therefore effective, mild, non- polluting and cheap desorbing agents should be used for regeneration of biomass to guarantee it's restoring close to the original state for use in multiple cycles with undiminished metal uptake, whenever it is possible.

Figure (4) showed the adsorption curves profiles of chromium for five times adsorption / desorption cycles using $0.1 \mathrm{M} \mathrm{NaOH}$ and $0.1 \mathrm{M} \mathrm{HCl}$ as desorption agents. It has been observed that throughout all adsorption / desorption cycles using any of the studied desorption agents, chromium adsorption significantly decreased following each cycle. After the first adsorption / desorption cycle using $\mathrm{NaOH}$, the examined dried biomass achieved chromium removal percentage of $15.04 \%$, which far less than that of the original state (96.76\%). The case has been reverse using $\mathrm{HCl}$, where $86.28 \%$ was the value of the chromium removal percentage. Accordingly, metal sorption by the biomass decreased greatly and slightly after each successive cycle using $\mathrm{NaOH}$ and $\mathrm{HCl}$, respectively. After five sorption/desorption cycles, $91.8 \%$ and $22 \%$ decrease in sorption was occurred using $\mathrm{NaOH}$ and $\mathrm{HCl}$, respectively. Taking into account the loss of biomass $(\approx 15-20 \%)$ at the end of the fifth cycle, it is apparent that the metal sorbing ability of the biomass did not considerably diminish during repeated sorption / desorption cycles using $\mathrm{HCl}$. This means that the regeneration process for chromium-loaded biomass was highly effective using $\mathrm{HCl}$ than $\mathrm{NaOH}$. Generally, the superiority of $\mathrm{HCl}$ for desorption of metals from the biomass may be attributed to that its efficiency is based on the competition between its protons and the heavy metal ions bound to active sites, which will be released if elutant concentration is high enough. i.e., the metal ions were displaced from the biomass by acid protons showing probable involvement of ion exchange. Similar findings were obtained by Lodeiro et al. (2006), who reported the acids as one of the best desorbent agents for metal desorption. Increasing the acidity generally leads to an 
effective removal of metals from the biomass. As acids do not deteriorate Oedogonium $s p$. biomass, this finding may have considerable bearing on the use of acids for metal desorption (Gupta et al., 2000; Gupta and Rastogi, 2008). On the other hand $\mathrm{HCl}$ is not only efficient in desorbing metal ions but is inexpensive as well.

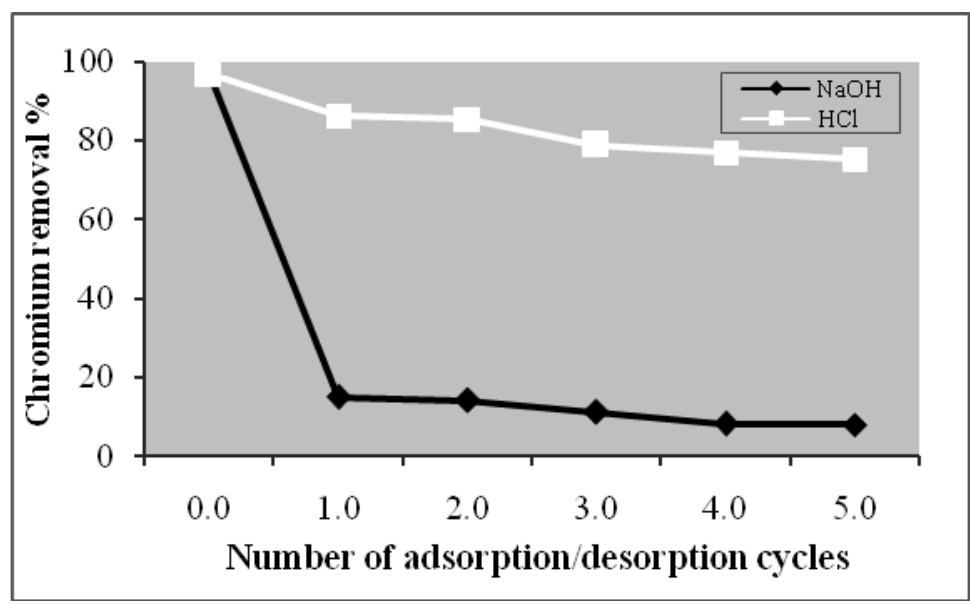

Figure (4): Effect of $0.1 \mathrm{M} \mathrm{NaOH}$ and $\mathrm{HCl}$ as desorption agents on the removal percentage of chromium by $S$. hornschuchii dry biomass

\section{Conclusion}

The performance of Mediterranean brown macroalga Sargassum hornschuchii for the removal of $\mathrm{Cr}$ (VI) from aqueous solution was evaluated through batch experiments. The removal percentage of metal was estimated as a function of contact time, algal dosage and $\mathrm{pH}$. It increased with increase in time and algal dosage and reached a plateau at $36 \mathrm{hrs}$ and $8 \mathrm{~g} \mathrm{~L}^{-1}$, respectively. The adsorption process was solution $\mathrm{pH}$ dependent and a maximum adsorption of metal was determined at $\mathrm{pH} 3$. The biomass was also employed for five times adsorption / desorption cycles with $0.1 \mathrm{M} \mathrm{NaOH}$ and $0.1 \mathrm{M} \mathrm{HCl}$ as desorbing agents. Lack of considerably diminishing in metal sorbing ability of the biomass during repeated sorption / desorption cycles using $\mathrm{HCl}$ favors it to be employed as a suitable metal desorbing agent for Sargassum hornschuchii. Consequently, dried biomass of Sargassum hornschuchii could be used as an alternative, inexpensive and effective material to remove high amounts of chromium ions from aqueous phase. 


\section{Acknowledgments}

The authors were grateful to the support by the Phycology Laboratory, Botany and Microbiology department, Faculty of Science and Biology Laboratory, Department of Biological and Geological Sciences, Faculty of Education, Alexandria University.

\section{References}

Anderson, R.A. (1997). Chromium as an essential nutrient for humans. Regulatory Toxicology and Pharmacology, 26:S35-41.

Antunes, W.M.; Luna, A.S.; Henriques, C.A. and da Costa, A.C. (2003). An evaluation of copper biosorption by a brown seaweed under optimized conditions. Electronic Journal of Biotechnology, 6(3):174-184.

Basha, S.; Murthy, Z.V.P. and Jha, B. (2007). Biosorption of hexavalent chromium by chemically modified seaweed, Cystoseira indica. Chemical Engineering Journal, 137(3): 480-488.

Bishnoi, N.R.; Kumar, R.; Kumar, S. and Rani, S. (2007). Biosorption of Cr (III) from aqueous solution using algal biomass Spirogyra spp. Journal of Hazardous Materials, 145(1-2):142-147.

Brinza, L.; Dring, M. J. and Gavrilescu, M. (2007). Marine micro- and macroalgal species as biosorbents for heavy metals. Environmental Engineering and Management Journal, 6:237- 251.

Brinza, L.; Nygard, C.A.; Dring, M.J.; Gavrilescu, M. and Benning, L.G. (2009). Cadmium tolerance and adsorption by the marine brown alga Fucus vesiculosus from the Irish Sea and the Bothnian Sea. Bioresource Technology, 100:1727-1733.

Cossich, E.S.; Tavares, C.R.G. and Ravagnani, T.M.K. (2002). Biosorption of chromium (III) by Sargassum sp. Biomass. Electronic Journal of Biotechnology, 5(2): 133-140.

Costa, M. (2003). Potential hazards of hexavalent chromate in our drinking water. Toxicology and Applied Pharmacology, 188 (1):1-5.

Davis, T.A. Volesky, B. and Vieira, R.H.S.F. (2000). Sargassum seaweed as biosorbent for heavy metals. Water Research, 34 (17): 4270-4278.

Deng, L.; Su, Y.; Su, H.; Wang, X. and Zhu, X. (2007). Sorption and desorption of lead (II) from wastewater by green algae Cladophora fascicularis. Journal of Hazardous Materials, 143:220-225.

Devi, B.S.; Mary, S.J.; Rajendran, S.; Manimaran, N.; Rengan, P.; Jayasundari, J. and Mannivannan, M. (2010). Removal of mercury by biosorption onto Sphaeroplea algae. Zaštita Materijala, 51(4):227-231.

Dirilgen, N. (1998). Effects of $\mathrm{pH}$ and chelators EDTA on Cr toxicity and accumulation in Lemna minor. Chemosphere, 37:771-783.

Dursun, A.Y. (2006). A comparative study on determination of the equilibrium, kinetic and thermodynamic parameters of biosorption of copper (II) and 
lead (II) ions onto pretreated Aspergillus niger. Biochemical Engineering Journal, 28:187-195.

El-Nady, F.E. and Atta, M.M. (1996). Toxicity and bioaccumulation of heavy metals to some marine biota from the Egyptian coastal waters. Journal of Environmental Science and Health, Part A., 31(7):1529-1545.

Esmaeili, A.; Beirami, P. and Ghasemi, S. (2011). Evaluation of the Marine Algae Gracilaria and its Activated Carbon for the Adsorption of Ni (II) from Wastewater. E-Journal of Chemistry, 8(4): 1512-1521.

Gong, R.; Ding, Y.; Lui, H.; Chem, Q. and Liu, Z. (2005). Lead biosorption and desorption by intact and pretreated Spirulina maxima biomass. Chemosphere, 58:125-130.

Gupta, R.; Ahuja, P.; Khan, S.; Saxena, R. K. and Mohapatra, H. (2000). Microbial biosorbents: Meeting challenges of heavy metal pollution in aqueous solutions. Current Science, 78 (8): 967-973.

Gupta, V.K. and Rastogi, A. (2008). Biosorption of lead from aqueous solution by green algae Spirogyra Species: Kinetics and Equilibrium Studies. Journal of Hazardous Materials, 152:407-414.

Gupta, V.K. and Rastogi, A. (2009). Biosorption of hexavalent chromium by raw and acid-treated green alga Oedogonium hatei from aqueous solutions. Journal of Hazardous Materials, 163:396-402.

Han, X.; Wong, Y.S.; Wong, M.H. and Tam, N.F.Y. (2007). Biosorption and bioreduction of $\mathrm{Cr}$ (VI) by a microalgal isolate, Chlorella miniata. Journal of Hazardous Materials, 146:65-72.

Hashim, M.A.; Tan, H.N. and Chu, K.H. (2000). Imnobiliced marine algal biomass for multiple cycles of copper adsorption and desorption. Separation and Purification Technology, 19:39-42.

Jalali, R.; Ghafourian, H.; Asef, Y.; Davarpanah, S.J. and Sepehr, S. (2002). Removal and recovery of lead using nonliving biomass of marine algae. Journal of Hazardous Materials, 92:253-262.

Karthikeyan, S.; Balasubramanian, R. and Iyer, C.S.P. (2007). Evaluation of the marine algae Ulva fasciata and Sargassum sp. for the biosorption of $\mathrm{Cu}$ (II) from aqueous solutions, Bioresource Technology, 98:452-455.

Kiran, I.; Akar, T. and Tunali, S. (2005). Biosorption of $\mathrm{Pb}$ (II) and $\mathrm{Cu}$ (II) from aqueous solution by pretreated biomass of Neurospora crassa. Process Biochemistry, 40 (11):3550-3558.

Kumar, P.S.; Ramakrishnan, K. and Gayathri, R. (2010). Removal of nickel (II) from aqueous solutions by Ceralite IR 120 cationic exchange resins. Journal of Engineering Science and Technology, 5 (2):232-243.

Kumar, Y. P.; King, P. and Prasad, V.S.R.K. (2006). Zinc biosorption on Tectona grandis L.f. leaves biomass: Equilibrium and kinetic studies. Journal of Chemical Engineering, 124:63-70. 
Kumar, Y. P.; King, P. and Prasad, V.S.R.K. (2007). Adsorption of zinc from aqueous solution using marine green algae Ulva fasciata sp. Journal of Chemical Engineering, 129:161-166.

Lia, Z.Y.; Guo, S.Y. and Li, L. (2006). Study on the process, thermodynamical isotherm and mechanism of $\mathrm{Cr}$ (III) uptake by Spirulina platensis. Journal of Food Engineering, 75:129-136.

Liu, Y.; Cao, Q.; Luo, F. and Chen, J. (2009). Biosorption of $\mathrm{Cd}^{2+}, \mathrm{Cu}^{2+}, \mathrm{Ni}^{2+}$ and $\mathrm{Zn}^{2+}$ ions from aqueous solutions by pretreated biomass of brown algae. Journal of Hazardous Materials, 163:931-938.

Lodeiro, P.; Herrero, R. and Sastre de Vicente, M.E. (2006). Batch desorption studies and multiple sorption-regeneration cycles in a fixed-bed column for Cd (II) elimination by protonated Sargassum muticum. Journal of Hazardous Materials, 127:1649-1655.

Mane, P.C.; Bhosle, A.B.; Vishwakarma, C.V. and Tupkar, L.G. (2010). Effect of pretreatment of algal biomass bioadsorption of manganese. International Journal of Engineering Science and Technology, 2(12):7550 7554.

Mehta, S.K. and Gaur, J.P. (2001). Characterization and optimization of Ni and $\mathrm{Cu}$ sorption from aqueous solution by Chlorella vulgaris. Ecological Engineering, 18:1-13.

Merrin, J.S.; Sheela, R.; Saswathi, N.; Prakasham, R.S. and Ramakrishna, S.V. (1998). Biosorption of chromium VI using Rhizopus arrhizus. Indian Journal of Experimental Biology, 36:1052-1055.

Murphy, V.; Hughes, H. and McLoughlin, P. (2008). Comparative study of chromium biosorption by red, green and brown seaweed biomass. Chemosphere, 70:1128-1134.

Onyancha, D.; Mavura, W.; Nigla, J.C.; Ongoma, P. and Chacha, J. (2008). Studies of chromium removal from tannery wastewaters by algae biosorbents, Spirogyra condensate and Rhizoclonium hieroglyphicum. Journal of Hazardous Materials, 158:605-614.

Parameswari, E.; Lakshmanan, A. and Thilagavathi, T. (2009). Effect of pretreatment of blue green algal biomass on bioadsorption of chromium and nickel. Journal of Algal Biomass Utilization, 1(1): 9 -17.

Rakesh, N.; Kalpana, P.; Rao, L.N.; Naidu, T.V.R. and Rao, M.V. (2010). Removal of zinc ions from aqueous solution by Ficus Benghalensis L.: equilibrium and kinetic studies. International Journal of Engineering Studies, 2(1):15-28.

Rezaee, A.; Derayat, J.; Mortazavi, S.B.; Yamini, Y. and Jafarzadeh, M.T. (2005). Removal of mercury from chlor-alkali industry wastewater using Acetobacter xylinum cellulose. American Journal of Environmental Sciences, 1:102-105. 
Rezaee, A.; Ramavandi, B.; Ganati, F.; Ansari, M. and Solimanian, A. (2006). Biosorption of mercury by biomass of filamentous algae Spirogyra species. Journal of Biological Sciences, 6 (4): 695-700.

Rocha, S.C.S.; Cavalcante, J.D.; da Silva, M.G.C. and Pinho, C.G. (2006). Influence of the drying conditions of Sargassum sp. alga on the bioadsorption of hexavalent chromium. Environmental Technology, 27(9):979-990.

Romera, E.; González, F.; Ballester, A.; Blázquez, M. L. and Muñoz, J. A. (2006). Biosorption with algae: a statistical review. Critical Reviews in Biotechnology, 26:223- 235.

Romera, E.; González, F.; Ballester, A.; Blázquez, M.L. and Muñoz, J.A. (2007). Comparative study of biosorption of heavy metals using different types of algae. Bioresource Technology, 98:3344-3353.

Saratale, R.G.; Saratale, G.D.; Chang, J.S. and Govindwar, S.P. (2009). Ecofriendly degradation of sulphonated diazo dye Reactive Green 19A using Micrococcus glutamicus NCIM 2168. Bioresource Technology, 100:3897-3905.

Sari, A. and Tuzen, M. (2008). Biosorption of total chromium from aqueous solution by red algae (Ceramium virgatum): Equilibrium, kinetic and thermodynamic studies. Journal of Hazardous Materials, 160:349-355.

Schiewer, S. and Volesky, B. (2000): Biosorption process of heavy metal removal. In: Environmental Microbe-Metal Interactions, Lovely, DR (ed.), ASM Press, Washington, DC, 329-362.

Senthilkumar, R.; Vijayaraghavan, K.; Thilakavathi, M.; Lyer, P.V.R. and Velan, M. (2006). Seaweeds for the remediation of wastewaters contaminated with zinc (II) ions. Journal of Hazardous Materials, 136:791799.

Singh, D. (2007). Removal of Ni(II) from aqueous solution by biosorption using two green algal species Oscillatoria sp. and Spirogyra sp. $5^{\text {th }}$ WSEAS Int. Conf. on Environment, Ecosystems and Development, pp. 310-314.

Smith, W.L. and Gadd, G.M. (2000). Reduction and precipitation of chromate by mixed culture sulphate-reducing bacterial biofilms. Journal of Applied Microbiology, 88:983-991.

Tan, P.; Wong, C.; Ong, S. and Hii, S. (2009). Equilibrium and kinetic studies for basic yellow removal by Sargassum binderi. Journal of Applied Sciences, 9(17):3005-3012.

Tsui, M.T.K.; Cheung, K.C.; Tam, N.F.Y. and Wong, M.H. (2006). A comparative study on metal sorption by brown seaweed. Chemosphere, 65:51-57.

Vijayaraghavan, K.; Jegan, J.R.; Palanivelu, K. and Velan, M. (2004). Copper removal from aqueous solution by marine green alga Ulva reticulate. Electronic Journal of Biotechnology, 7 (1): 61-71.

Egyptian J. of Phycol. Vol. 14, 2013 
Zhao, M.; Duncan, J.R. and Van Hille, R.P. (1999). Removal and recovery of zinc from solution and electroplating effluent using Azolla filiculoides. Water Research, 331:1516-1522.

$$
\begin{aligned}
& \text { ادمصاص الكروم باستخدام الكتلة الجافة من الطحلب البني سارجسام } \\
& \text { هورنشوشاي } \\
& \text { ايمان محمد فخري 1، سوزان احمد اسماعيل، نادية حجازي نعمان، ماجدة علي شفيق² } \\
& \text { وفاء محمود منيسي } \\
& \text { 1- ق قسم النبات والميكروبيولوجى، كلية العلوم، جامعة الأسكندريه، مصر. } \\
& \text { 2- قسم البيولوجى والجبيولوجيا، كلية التربيه، جامعة الأسكندريه، مصر. }
\end{aligned}
$$

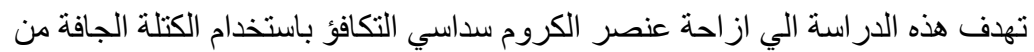

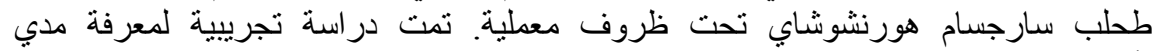

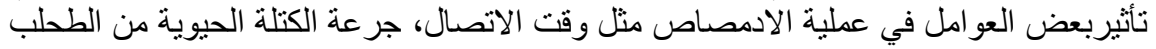

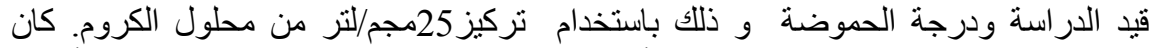

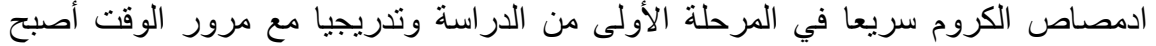

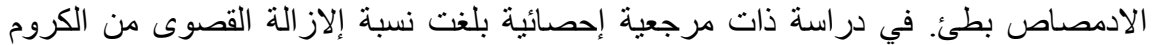

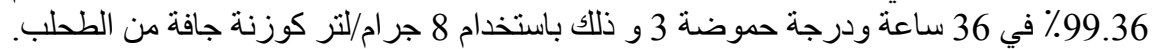
تم تثغيل خمس دور في مات من الادمصاص / الاستعادة متتالية باستخدام

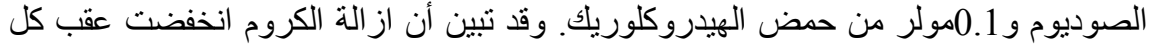

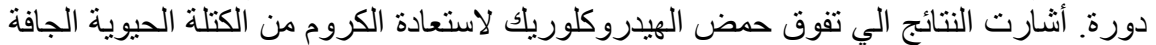

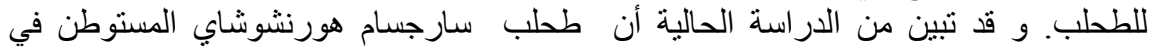
شو اطنئا بالبحر المتوسط له قدرة كبيرة على إز احة الكروم من المحلول المائي. 